\title{
Endogenous hydrogen sulfide contributes to uterine quiescence during pregnancy
}

\author{
Xingji You ${ }^{1}$, Zixi Chen, Huina Zhao ${ }^{2,3}$, Chen Xu, Weina Liu, Qianqian Sun², Ping He ${ }^{1}$, \\ Hang $\mathrm{Gu}^{2}$ and $\mathrm{Xin} \mathrm{Ni}^{1}$ \\ ${ }^{1}$ Department of Physiology, ${ }^{2}$ Department of Obstetrics and Gynecology, Changhai Hospital, Second Military \\ Medical University, Shanghai, China and ${ }^{3}$ Department of Obstetrics and Gynecology, Seventh People's Hospital of \\ Shanghai University of Traditional Chinese Medicine, Shanghai, China
}

Correspondence should be addressed to X Ni; Email: nixin@smmu.edu.cn

* (X You and Z Chen contributed equally to this work)

\begin{abstract}
Recent evidence suggests that uterine activation for labor is associated with inflammation within uterine tissues. Hydrogen sulfide $\left(\mathrm{H}_{2} \mathrm{~S}\right)$ plays a critical role in inflammatory responses in various tissues. Our previous study has shown that human myometrium produces $\mathrm{H}_{2} \mathrm{~S}$ via its generating enzymes cystathionine- $\gamma$-lyase (CSE) and cystathionine- $\beta$-synthetase (CBS) during pregnancy. We therefore explored whether $\mathrm{H}_{2} \mathrm{~S}$ plays a role in the maintenance of uterine quiescence during pregnancy. Human myometrial biopsies were obtained from pregnant women at term. Uterine smooth muscle cells (UMSCs) isolated from myometrial tissues were treated with various reagents including $\mathrm{H}_{2} \mathrm{~S}$. The protein expression of CSE, CBS and contraction-associated proteins (CAPs) including connexin 43 , oxytocin receptor and prostaglandin $F_{2 \alpha}$ receptor determined by Western blot. The levels of cytokines were measured by ELISA. The results showed that CSE and CBS expression inversely correlated to the levels of CAPs and activated NF- $\kappa B$ in pregnant myometrial tissues. $\mathrm{H}_{2} \mathrm{~S}$ inhibited the expression of CAPs, NF- $\mathrm{KB}$ activation and the production of interleukin (IL)-1 $\beta$, IL-6 and tumor necrosis factor $\alpha(T N F)$ in cultured USMCs. IL-1 $\beta$ treatment reversed $\mathrm{H}_{2} \mathrm{~S}$ inhibition of CAPs. Knockdown of CSE and CBS prevented $\mathrm{H}_{2} \mathrm{~S}$ suppression of inflammation. $\mathrm{H}_{2} \mathrm{~S}$ modulation of inflammation is through $\mathrm{K}_{\mathrm{ATP}}$ channels and phosphoinositide 3-kinase (PI3K) and extracellular signal-regulated kinase (ERK) signaling pathways. $\mathrm{H}_{2} \mathrm{~S}$ activation of PI3K and ERK signaling is dependent on $\mathrm{K}_{\mathrm{ATP}}$ channels. Our data suggest that $\mathrm{H}_{2} \mathrm{~S}$ suppresses the expression of CAPs via inhibition of inflammation in myometrium. Endogenous $\mathrm{H}_{2} \mathrm{~S}$ is one of the key factors in maintenance of uterine quiescence during pregnancy.

Reproduction (2017) 153 535-543
\end{abstract}

\section{Introduction}

Preterm birth is the prevalent cause of mortality and morbidity in newborn infants. Moreover, the survivors of preterm birth have increased risk of neurodevelopmental impairments, gastrointestinal and respiratory complications (Liu et al. 2012). So far, it lacks effective methods of prediction or prevention for preterm birth. This failure is largely due to our incomplete understanding of the process that maintains uterus in a relatively noncontractile state throughout most of pregnancy and converts it into a procontractile state toward the end of pregnancy.

Human uterine conversion into the procontractile state results from the coordinated expression of a cassette of contraction-associated proteins (CAPs) such as gap junction, ion channels and the receptors of agonists (such as oxytocin and prostaglandins) (Challis et al. 2000), thereby making the uterus to respond to hormonal signals and mechanical forces.
In the past decade, increasing body of evidence suggests that uterine activation for labor in women is associated with inflammatory responses within uterine tissues (Romero et al. 2006, Rinaldi et al. 2011, Shynlova et al. 2013). Toward the end of pregnancy, uterine tissues display inflammatory response, which is characterized by an influx of inflammatory cells into the myometrium and cervix with concomitant increases in vascular and leukocyte adhesion molecule expression, activation of NF- $\mathrm{KB}$ and increased production of chemokines and proinflammatory cytokines in uterus (Thomson et al. 1999, Osman et al. 2003, Gomez-Lopez et al. 2011). However, the mechanisms underlying modulation of inflammatory response in uterus remain unclear.

Hydrogen sulfide $\left(\mathrm{H}_{2} \mathrm{~S}\right)$, the third endogenous gaseous transmitter, has been implicated to be involved in many physiological and pathophysiological processes including angiogenesis (Papapetropoulos et al. 2009), vasodilation (Skovgaard et al. 2011) and 
inflammation (Wallace et al. 2012). $\mathrm{H}_{2} \mathrm{~S}$ is generated from L-cysteine principally through two pyridoxal5-phosphate-dependent enzymes: cystathionine- $\gamma$ lyase (CSE, EC4.4.1.1) and cystathionine- $\beta$-synthetase (CBS, EC 4.2.1.22) (Li et al. 2011). Both CBS and CSE have been identified in gestational tissues including placenta and myometrium (Holwerda et al. 2012, Hu et al. 2016). Our previous study has shown that endogenous $\mathrm{H}_{2} \mathrm{~S}$ produced by CSE and CBS suppresses the spontaneous contractility of pregnant human myoemtrial strips (You et al. 2011). Furthermore, we have also demonstrated that CSE and CBS expression levels and production of $\mathrm{H}_{2} \mathrm{~S}$ in human myometrium are decreased with the onset of labor (You et al. 2011), suggesting that endogenous $\mathrm{H}_{2} \mathrm{~S}$ is involved in the initiation and progress of labor in women.

Based on the above background, we hypothesized that endogenous $\mathrm{H}_{2} \mathrm{~S}$ produced locally may play a role in the maintenance of uterine quiescence via modulation of uterine inflammation during human pregnancy. To test it, we firstly analyzed the correlation between the expression of CAPs and level of CSE and CSE in myometrium obtained from pregnant women at term. We then studied the effect of $\mathrm{H}_{2} \mathrm{~S}$ on the expression of CAPs, investigated whether $\mathrm{H}_{2} \mathrm{~S}$ regulates CAPs via the modulation of inflammatory responses and elucidated molecular mechanisms involved in a model of primary human uterine smooth muscle cells (USMCs). Our data indicate that endogenous $\mathrm{H}_{2} \mathrm{~S}$ contributes to the maintenance of uterine quiescence via inhibition of inflammation during pregnancy.

\section{Materials and methods}

\section{Tissue collection}

This study was approved by the specialty committee on ethics of biomedicine research, Second Military Medical University, Shanghai, China. Written informed consent was obtained from all patients. Biopsies of human myometrium were obtained at cesarean section from the following group of pregnant women: term no labor (TNL, $n=23$ ) and term labor (TL, $n=21)$. The average gestational age of these two groups was 38 weeks, with a range of 37-42 weeks. Labor was defined as regular contractions ( $<5 \mathrm{~min}$ apart) plus membrane rupture and cervical dilation $(>3 \mathrm{~cm})$ with no augmentation (oxytocin or prostaglandin administration). None of the women included in this study had evidence of underlying disease (e.g. hypertension, diabetes, preeclampsia, intrauterine growth restriction, etc.). Biopsies were excised from the middle portion of upper edge of the incision line in the lower uterine segment. All myometrial samples were dissected free of serosa and immediately placed in Kreb's solution and maintained at $4{ }^{\circ} \mathrm{C}$ and transported to the laboratory for cell culture or frozen immediately in liquid nitrogen and stored at $-80^{\circ} \mathrm{C}$ for the subsequent Western blot analysis.

\section{Cultures of USMCS}

USMCs were isolated from TNL myometrial tissues as described previously (You et al. 2012). Briefly, myometrial tissue pieces were incubated with DMEM containing $1 \mathrm{mg} / \mathrm{mL}$ collagenase type II (Invitrogen) and $1 \mathrm{mg} / \mathrm{mL}$ deoxyribonuclease I (SigmaAldrich) at $37^{\circ} \mathrm{C}$ with shaking for $30 \mathrm{~min}$ for two times. After filtration, the cell suspension was centrifuged and the cell pellet was resuspended in DMEM containing $10 \%$ fetal calf serum (FCS), penicillin $(100 \mathrm{U} / \mathrm{mL})$ and streptomycin $(100 \mathrm{mg} /$ $\mathrm{mL}$ ). The cells were then plated into $25 \mathrm{~cm}^{2}$ flasks and kept at $37^{\circ} \mathrm{C}$ in $5 \% \mathrm{CO}_{2}-95 \%$ air-humidified atmosphere until confluent ( 2 week). The experiments were performed with the cells at passage 2 . The cells were seeded in 12-well plates and then treated with the following reagents for $24 \mathrm{~h}$ : NaHS $\left(5-100 \times 10^{-6} \mathrm{M}\right)$, L-cysteine $\left(1.25-10 \times 10^{-4} \mathrm{M}\right)$, glibenclamide $\left(10^{-5} \mathrm{M}\right)$, PD98059 $\left(10^{-5} \mathrm{M}\right), \mathrm{LY} 294002\left(10^{-5} \mathrm{M}\right)$ and interleukin (IL)-1 $\beta(1 \mathrm{ng} / \mathrm{mL})$. The vehicle control was set without additive. In some cases, the cells were treated with $\mathrm{NaHS}\left(10^{-4} \mathrm{M}\right)$, L-cysteine $\left(10^{-3} \mathrm{M}\right)$ or vehicle for $5,10,30$ and $60 \mathrm{~min}$. All of the previously mentioned reagents were purchased from Sigma-Aldrich. Each treatment was performed in triplicate for each preparation of cells. The concentrations of previously mentioned reagents were determined based on our previous studies (You et al. 2011, Hu et al. 2016) and preliminary data. To assess the purity of myocyte cultures, we routinely performed immunocytochemistry using $\alpha$-actin monoclonal antibody (Sigma-Aldrich).

\section{Enzyme-linked immunosorbent assay (ELSIA)}

The concentrations of IL-6, IL- $1 \beta$ and tumor necrosis factor (TNF) $\alpha$ in culture media of USMCs were determined with specific ELSIA (R\&D Systems) according to the manufacturer's instructions.

\section{Western blot analysis}

Myometrial tissues were homogenized in cold T-Per lysis buffer (Pierce), and primary HUSMCs were harvested in the presence of M-Per lysis buffer (Pierce). The amounts of up to $50 \mu \mathrm{g}$ of protein samples were separated by $10 \%$ SDS-PAGE and subsequently transferred to nitrocellulose membranes. After incubation with blocking buffer, the membranes were incubated with specific antibodies: CBS (ab131155, Abcam), CSE (ab133212, Abcam), connexin 43 (CX43) (ab11370, Abcam), oxytocin receptor (OTR) (sc-33209, Santa Cruz), prostaglandin $F_{2 \alpha}$ receptor (PGFR) (sc-67029, Santa Cruz), p65 (ab131485, Abcam), phospho-p65 (ser-529) (ab97726, Abcam), extracellular signal-regulated kinase (ERK)1/2 (4695, Cell signaling), phospho-ERK1/2 (4370, Cell signaling), phosphoinositide 3-kinase (PI3K) (sc-377482, Santa Cruz) and phospho-PI3K (Tyr508) (sc-12929, Santa Cruz) overnight at $4^{\circ} \mathrm{C}$ at a dilution of $1: 1000$. Then, the membrane was incubated with a secondary horseradish peroxidase-conjugated antibody for $1 \mathrm{~h}$ at room temperature. Immunoreactive proteins were visualized using the enhanced chemiluminescence Western blotting detection system (Santa Cruz). The chemiluminescent signal from the membranes was quantified by a GeneGnome HR scanner using GeneTools software (SynGene). To control 
Table 1 List of primers used for the amplification of chemokines and cytokines in USMCs.

\begin{tabular}{llcc}
\hline Name & Sense $\left(\right.$ S) and antisense $\left(\right.$ A) primer sequence $\left(5^{\prime}-3^{\prime}\right)$ & Genbank/EM BL accession no. & Production size $($ bp $)$ \\
\hline IL-1 $\beta$ & A: 5'-GTGGCAATGAGGATGACTT-3' & NM_000576 & 537 \\
IL-6 & S: 5'-TGGGCTTATCATCTTTCAA-3' & NM_000600 & 165 \\
A: 5'-CCTTCCAAAGATGGCTGAAA-3' & & \\
TNF- $\alpha$ & S: 5'-AGCTCTGGCTTGTTCCTCAC-3' & NM_000594 \\
& A: 5'-GCCCCCAGAGGGAAGAGTTCCCCA-3' & & 124 \\
\hline
\end{tabular}

sampling errors, the ratio of band intensities to the $\beta$-actin was obtained to quantify the relative protein expression level.

\section{Total RNA extraction and quantitative real-time RT-PCR}

Total RNA was prepared from myometrial tissues and cells using TRIzol reagent (Invitrogen). Two micrograms RNA were reverse transcribed with oligo(dT)18 primer using the M-MLV reverse transcriptase (Promega). Specific primers for the amplification of IL-1 $\beta$, IL- 6 and TNF $\alpha$ were listed in Table 1. Quantitative real-time PCR was carried out using Rotor-Gene 3000 (Corbett Research, Sydney, Australia). The reaction solution consisted of $2.0 \mu \mathrm{L}$ diluted cDNA product, $0.2 \mu \mathrm{mol} / \mathrm{L}$ of each paired primer, $200 \mu \mathrm{mol} / \mathrm{L}$ deoxynucleotide triphosphates, $1 \cup$ Taq DNA polymerase (Qiagen) and 1× PCR buffer. SYBRGreen (Roche) was used as a detection dye. The annealing temperature was set at $60^{\circ} \mathrm{C}$ and amplification cycles were set at 40 cycles. The temperature range to detect the melting temperature of the PCR product was set from $60^{\circ} \mathrm{C}$ to $95^{\circ} \mathrm{C}$. To determine the relative quantitation of gene expression for both target and housekeeping genes, the comparative $\mathrm{Ct}$ (threshold cycle) method with arithmetic formulae was used (Li et al. 2016). Two reference genes $\beta$-actin and GAPDH were measured for each sample as an internal control for sample loading and normalization. Messenger RNA levels were normalized relative to $\beta$-actin and GAPDH values respectively. Because very similar results were obtained using these two reference genes, the results were illustrated using $\beta$-actin as internal control.

\section{RNA interferences}

The small interfering RNA (siRNA) for CBS and CSE were designed and synthesized by GenePharma Corporation (Shanghai, China). Control siRNA was scrambled sequence without any specific known target. The sequences for targeting human CSE and CBS are CSE sense: 5'-GGCCUUUGCUUCAGGUUUATT-3', antisense: 5'-UAAACCUGAAGCAAAGGCCTT-3'; CBS sense: 5'-CGGAACUACAUGACCAAGUTT-3', antisense: 5'-ACUUGGUCAUGUAGUUCCGTT-3'. Transfection of siRNA was performed by using Lipofectamine TM 2000 as described previously (You et al. 2011, Hu et al. 2016).

\section{Statistical analysis}

Data are presented as mean \pm S.E.M. In some cases, for illustrative purposes, the results are presented as the mean percent control \pm S.E.M. All data were tested for homogeneity of variance by Bartlett's test before statistical analysis. The data of CAP expression and NFאB activation in TNL and TL tissues were analyzed by $t$ test. Pearson's correlation was used to explore the relationships of CBS or CSE with CX43, OTR, PGFR and activated NF- $\kappa B$ level in myometrium. The data of cultured USMCs were analyzed by a one-way ANOVA followed by a Student-Newman-Keuls test. A $P$ value $<0.05$ was considered significant.
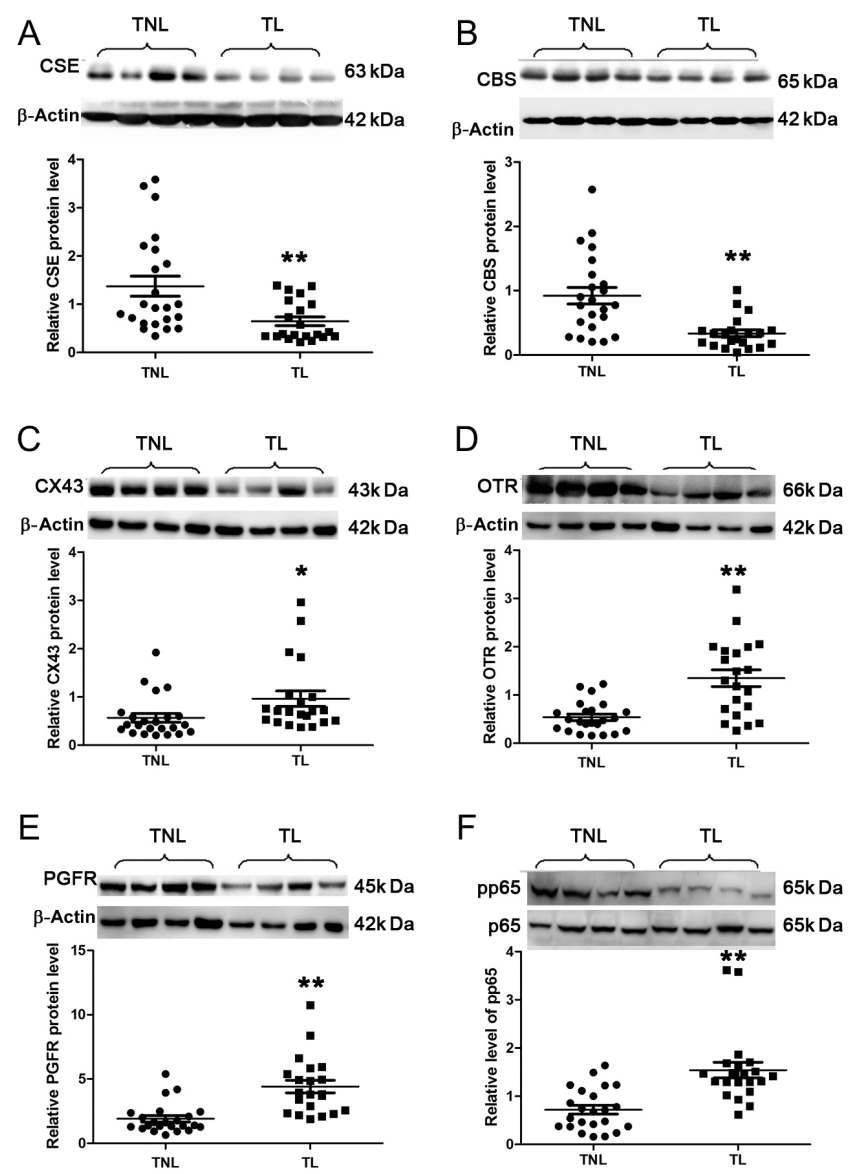

Figure 1 The protein levels of CBS, CSE, p-p65, CX43, OTR and PGFR, in pregnant myometrium before and after onset of labor. Myometrial tissues were obtained from pregnant women at term before (TNL) or after the onset of labor (TL). Semi-quantitation of Western blot signals of CBS (A), CSE (B), p-p65 (C), CX43 (D), OTR (E) and PGFR (F) in TNL and TL myometrium biopsies. Representative protein bands were on the top of each histogram. Data were presented as mean \pm S.E.M. ${ }^{* *} P<0.01$ vs TNL. 


\section{Results}

\section{The expression levels of CSE and CBS correlate to levels of CAPs and NF- $\mathrm{B} B$ in human pregnant myometrium}

As expected, the protein levels of CSE and CBS were downregulated in TL myometrial tissues compared with TNL tissues (Fig. $1 \mathrm{~A}$ and $\mathrm{B}$ ). Prior studies have shown that the expression of CAPs, such as CX43, OTR and PGFR, and the level of phospho-p65 (p-p65), active form of NF-kB are increased with labor (Condon et al. 2006, Kamel 2010). We therefore examined the protein levels of these proteins and found that the levels of CX43, OTR, PGFR and phospho-p65 were significantly increased in TL myometrial tissues compared with TNL tissues (Fig. 1C, D, E and F). The correlation analysis showed that the level of CSE and CBS inversely correlated to CX43, OTR, PGFR and active NF-kB level (Supplementary Fig. 1, see section on supplementary data given at the end of this article).

\section{NaHS and L-cysteine inhibit the expression of CX43, OTR and PGFR in USMCs}

We then investigated whether $\mathrm{H}_{2} \mathrm{~S}$ modulates CX43, OTR and PGFR expression in primary USMCs. As shown in Fig. 2A, B and C, treatment of USMCs with increasing concentration of $\mathrm{NaHS}\left(5 \times 10^{-6}-10^{-4} \mathrm{M}\right)$, the $\mathrm{H}_{2} \mathrm{~S}$ donor, caused a decrease in the expression of CX43, OTR and PGFR in a dose-dependent manner in a 24-h incubation time. L-cysteine $\left(1.25-10 \times 10^{-4} \mathrm{M}\right)$, the precursor of $\mathrm{H}_{2} \mathrm{~S}$, treatment also dose-dependently suppressed CX43, OTR and PGFR expression (Fig. 2D, E and F).

\section{$\mathrm{NaHS}$ and L-cysteine suppresses NFKB activation and production of proinflammatory cytokines in USMCs}

Prior studies have shown that $\mathrm{H}_{2} \mathrm{~S}$ suppresses NF-kB activation in macrophages (Du et al. 2014). We therefore examined whether $\mathrm{H}_{2} \mathrm{~S}$ treatment affects NF- $\mathrm{KB}$ activation in USMCs. As shown in Fig. $3 \mathrm{~A}$ and $\mathrm{B}$, treatment of cells with $\mathrm{NaHS}\left(10^{-4} \mathrm{M}\right)$ and L-cysteine $\left(10^{-3} \mathrm{M}\right)$ for $5-60 \mathrm{~min}$ decreased $\mathrm{p}$-p65 level in a timedependent manner.

As NF-kB plays a key role in driving cytokine and chemokine production. We explored whether $\mathrm{H}_{2} \mathrm{~S}$ modulates the production of proinflammatory cytokines and chemokines. As shown in Fig. 3C, $\mathrm{D}$ and $\mathrm{E}, \mathrm{NaHS}\left(5 \times 10^{-6}-10^{-4} \mathrm{M}\right)$ treatment dosedependently inhibited IL-1 $\beta$, IL- 6 and TNF $\alpha$ output in USMCs. Treatment of the cells with L-cysteine also caused a decrease in the output of IL-1 $\beta$, IL- 6 and TNF $\alpha$ in a dose-dependent manner (Fig. 3F, G and $\mathrm{H})$. Both NaHS and L-cysteine significantly inhibited IL-1 $\beta$, IL-6 and TNF $\alpha$ mRNA expression (Fig. 3C, D, E, F, G and H). However, NaHS and L-cysteine had no effect on the output of chemokines CCL-2 and CXCL-8 (Supplementary Fig. 2).

\section{The role of CSE and CBS in L-cysteine suppression of proinflammatory cytokine production in USMCs}

To explore the role of CSE and CBS in the effects of L-cysteine on inflammatory cytokine production, small interfering RNA (siRNA) approach targeting CSE and
A
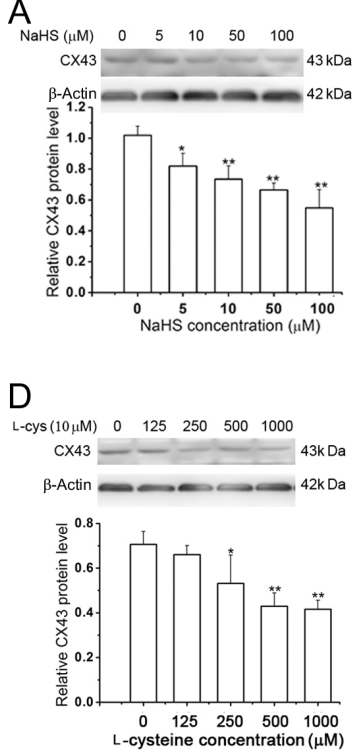

Reproduction (2017) 153 535-543
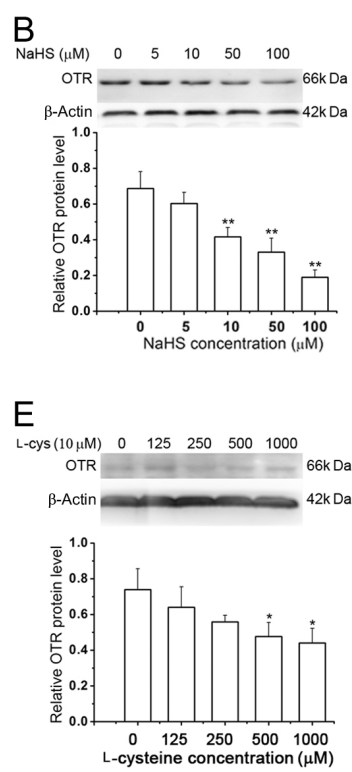

F

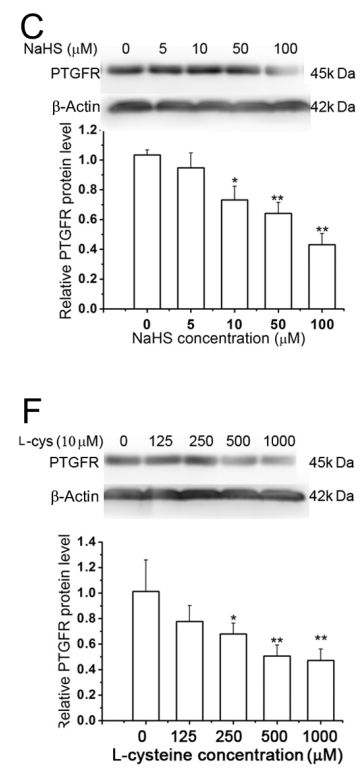

Figure 2 The effects of hydrogen sulfide on the expression of CX43, OTR and PGFR in USMCs. USMCs were treated with increasing concentration of $\mathrm{NaHS}\left(5 \times 10^{-6}-10^{-4} \mathrm{M}\right)$ or L-cysteine $\left(1.25-10 \times 10^{-4} \mathrm{M}\right)$ for $24 \mathrm{~h}$. The cells were then collected and protein levels of CX43 ( $A$ and D), OTR ( $B$ and $E$ ) and PGFR ( $C$ and $F$ ) were determined by Western blot. Values are presented as mean \pm S.E.M. for $n=6$ subjects performed in triplicate.

${ }^{*} P<0.05,{ }^{*} P P<0.01$ vs vehicle control. L-cys, L-cysteine. 
A

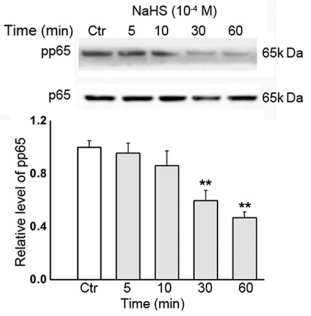

C

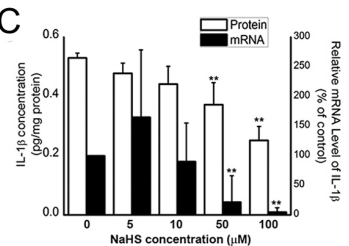

$\mathrm{F}$

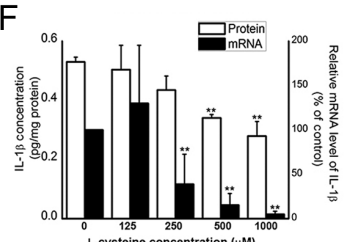

I

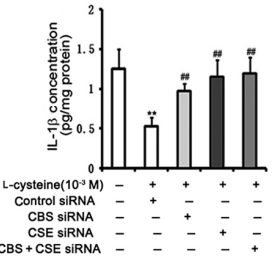

B

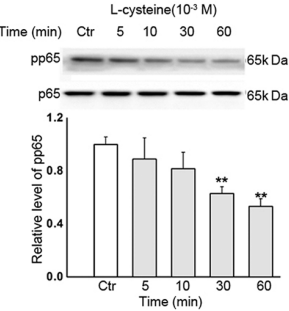

D

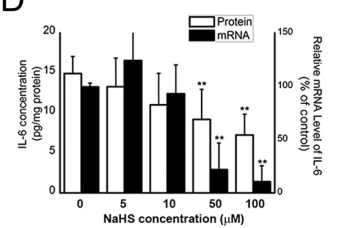

G

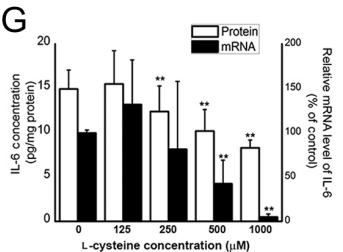

J

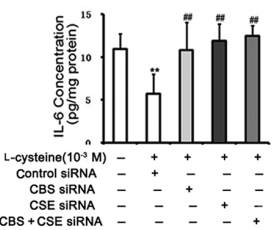

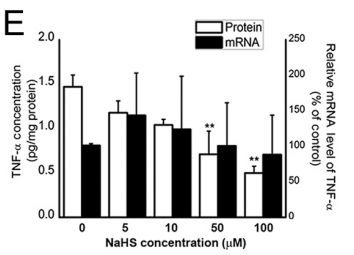

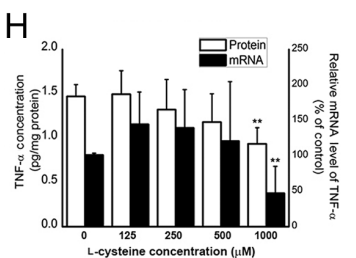

K

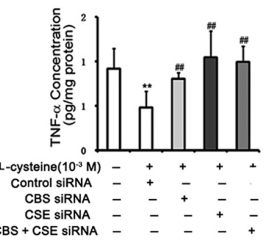

Figure 3 The effects of hydrogen sulfide on $\mathrm{NF}-\mathrm{kB}$ activation and the production of cytokines in USMCs. (A, B, C, D, E, F, G and H) USMCs were treated with $\mathrm{NaHS}$ $\left(5 \times 10^{-6}-10^{-4} \mathrm{M}\right)$ or L-cysteine $(1.25$ $\left.10 \times 10^{-4} \mathrm{M}\right)$ for $24 \mathrm{~h}$. The cells were collected for determination of the levels of protein levels of p-p65 (A and B) using Western blot and mRNA levels of IL-1 $\beta$ (C and F), IL-6 (D and G) and TNF $\alpha(E$ and $H)$ by quantitative real-time RT-PCR. The supernatant was collected and levels of IL-1 $\beta$ (C and F), IL-6 (D and G) and TNF $\alpha(E$ and $H)$ were measured by ELISA. Values are presented as mean \pm S.E.M. for $n=6$ subjects performed in triplicate. Representative protein bands of p-p65 were on the top of each histogram. (I, J and K) USMCs were transfected with siRNA targeting CSE or CBS for $10 \mathrm{~h}$ and changed medium with DMEM for $14 \mathrm{~h}$ and then followed by L-cysteine $\left(10^{-4} \mathrm{M}\right)$ treatment for $24 \mathrm{~h}$. The supernatant was collected and levels of IL-1 $\beta$ (I), IL-6 (J) and TNF $\alpha(\mathrm{K})$ were measured by ELISA. Values are presented as mean \pm S.E.M. for $n=3$ subjects performed in triplicate. ${ }^{*} P<0.05,{ }^{*} P<0.01$ vs vehicle control.
CBS was applied. The protein level of CSE and CBS was decreased by about $68 \%$ and $91 \%$ respectively, upon transfection with CSE and CBS siRNA (Supplementary Fig. 3). As shown in Fig. 3G, $\mathrm{H}$ and $\mathrm{I}$, knockdown of either CSE or CBS reversed L-cysteine inhibition of the output of proinflammatory cytokines.

\section{IL-1 $\beta$ blocks NaHS and L-cysteine suppression of CX43, OTR and PGFR expression}

We then investigated the effects of proinflammatory cytokines on $\mathrm{H}_{2} \mathrm{~S}$ inhibition of the expression of CAPs. As shown in Fig. 4, the inhibitory effect of $\mathrm{H}_{2} \mathrm{~S}$ on CX43,
A

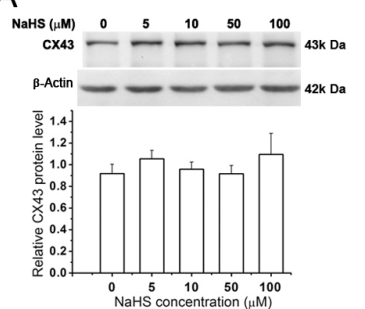

D
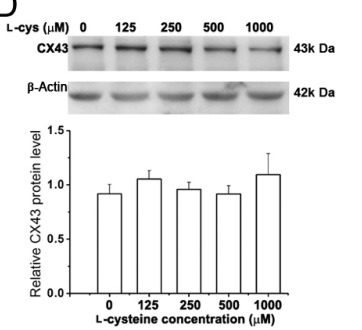

B

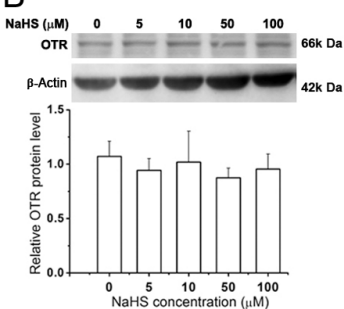

E
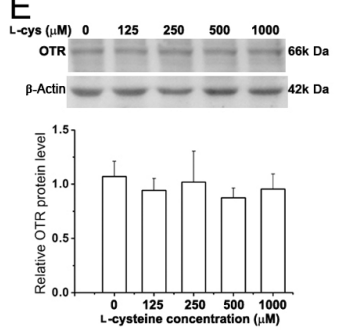

C

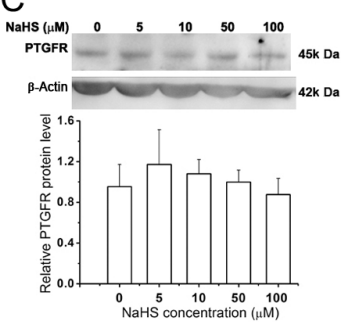

$\mathrm{F}$

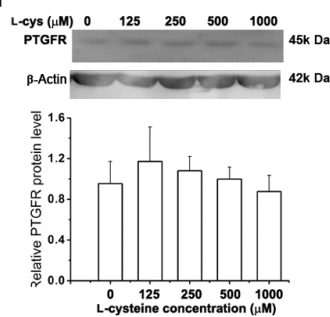

Figure 4 The effects of $\mathrm{H}_{2} \mathrm{~S}$ on $\mathrm{CX} 43$, OTR and PGFR expression in the presence of IL-1 $\beta$. USMCs were treated with NaHS $\left(5 \times 10^{-6}-10^{-4} \mathrm{M}\right)$ or L-cysteine $\left(1.25-10 \times 10^{-4} \mathrm{M}\right)$ in the presence of IL-1 $\beta$ $(1 \mathrm{ng} / \mathrm{mL})$ for $24 \mathrm{~h}$. Cells were collected for determination of the protein levels of CX43 ( $A$ and $D)$, PGFR (B and E) and OTR (C and F) by Western blot analysis. Representative protein bands are presented on the top of the responding histogram. Values are presented as mean \pm S.E.M. for $n=4$ subjects performed in triplicate. ${ }^{*} P<0.05,{ }^{*} P<0.01$ vs vehicle control. L-cys, L-cysteine. 
OTR and PGFR expression did not occur in the presence of IL-1 $\beta$.

\section{The role of $K_{A T P}$ channels in NaHS and L-cysteine suppression of proinflammatory cytokines}

We explored the role of $\mathrm{K}_{\text {ATP }}$ channels in $\mathrm{H}_{2} \mathrm{~S}$ suppression of proinflammatory cytokines because $\mathrm{K}_{\text {ATP }}$ channels have been reported to mediate $\mathrm{H}_{2} \mathrm{~S}$ action in many studies (Jiang et al. 2010, Tang et al. 2010). As shown in Fig. 5A, B and C, $\mathrm{K}_{\text {ATP }}$ channel inhibitor glibenclamide $\left(10^{-5} \mathrm{M}\right)$ reversed $\mathrm{NaHS}$ and L-cysteine inhibition of IL-1 $\beta$, IL- 6 and TNF $\alpha$ output.

\section{PI3K and ERK signaling pathways are involved in $\mathrm{NaHS}$ and L-cysteine suppression of proinflammatory cytokines}

Prior studies have also reported that $\mathrm{H}_{2} \mathrm{~S}$ can activate $\mathrm{PI} 3 \mathrm{~K}$ and ERK signaling in some tissues (Hu et al. 2008, Tamizhselvi et al. 2009, Ang et al. 2011, Peake et al. 2013). We therefore examined the role of $\mathrm{PI} 3 \mathrm{~K}$ and ERK signaling in the $\mathrm{H}_{2} \mathrm{~S}$ modulation of proinflammatory cytokine output. It was found that the PI3K inhibitor LY294002 and ERK inhibitor PD98059 could block the inhibitory effects of NaHS and L-cysteine on IL-1 $\beta$, IL- 6 and TNF $\alpha$ production (Fig. 5D, E and F).

As shown in Fig. 5G, $\mathrm{H}, \mathrm{I}$ and $\mathrm{J}$, treatment of cells with $\mathrm{NaHS}\left(10^{-4} \mathrm{M}\right)$ and L-cysteine $\left(10^{-3} \mathrm{M}\right)$ for 5-60 min increased phospho-PI3K (p-PI3K) and phospho-ERK1/2 ( $p$-ERK1/2) levels in a time-dependent manner.

\section{NaHS and L-cysteine activation of PI3K and ERK signaling is dependent on $K_{A T P}$ channels}

We investigated whether $\mathrm{H}_{2} \mathrm{~S}$ activation of PI3K and ERK signaling is associated with activation of $K_{\text {ATP }}$ channels. As shown in Fig. 6A and B, in the presence of glibenclamide $\left(10^{-5} \mathrm{M}\right)$, the effects of $\mathrm{NaHS}$ and L-cysteine treatment on PI3K and ERK activation did not occur.

We then examined whether $\mathrm{H}_{2} \mathrm{~S}$ suppression of NF-kB activation is dependent on $\mathrm{K}_{\text {ATP }}$ channels. Glibenclamide $\left(10^{-5} \mathrm{M}\right)$ treatment did not affect $\mathrm{NaHS}$ and L-cysteine inhibition of p-p65 level (Fig. 6C and D).

\section{Discussion}

The present study showed for the first time that both $\mathrm{H}_{2} \mathrm{~S}$ donor $\mathrm{NaHS}$ and $\mathrm{H}_{2} \mathrm{~S}$ precursor L-cysteine exhibited suppressive effects on CAP expression and NF-kB activation in cultured USMCs obtained for pregnant myometrial biopsies. NaHS and L-cysteine also inhibited the production of proinflammatory cytokines including IL-1 $\beta$, IL- 6 and TNF $\alpha$. Knockdown of CSE or CBS reversed suppressive effects of L-cysteine on inflammation, confirming the effects of endogenous $\mathrm{H}_{2} \mathrm{~S}$ produced via CSE and CBS. Moreover, IL-1 $\beta$ blocked the inhibitory effect of $\mathrm{H}_{2} \mathrm{~S}$ on the expression of CAPs in myometrium. Thus, our study indicated that $\mathrm{H}_{2} \mathrm{~S}$ suppresses uterine activation by inhibition of inflammation.

Many previous studies have reported that $\mathrm{H}_{2} \mathrm{~S}$ has anti-inflammatory actions in various tissues, such as inhibition of leukocyte adhesion and the release

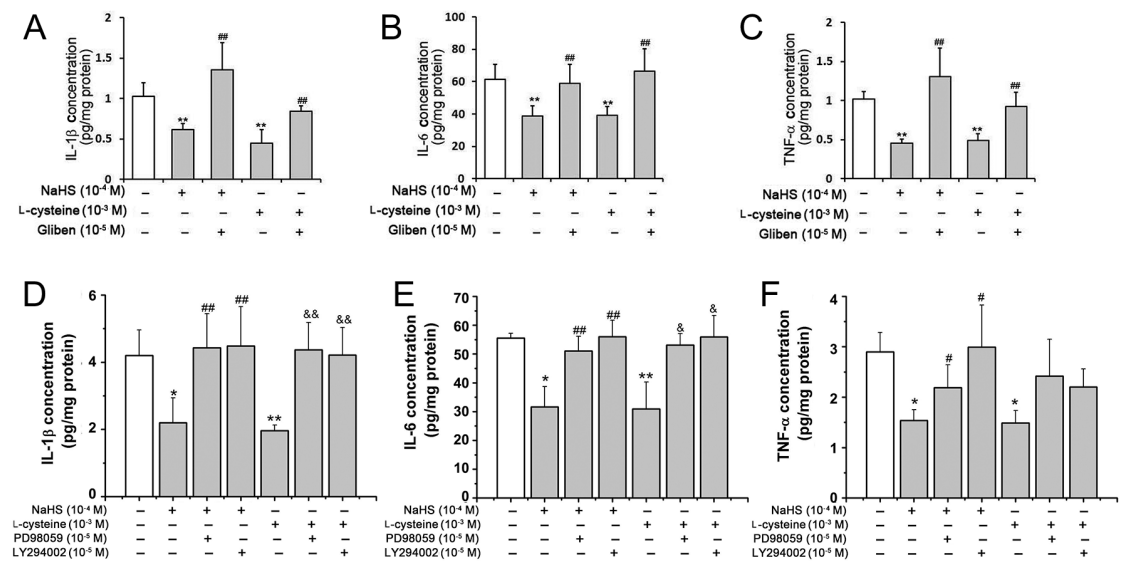

Figure 5 The roles of $\mathrm{K}_{\text {ATP }}$ channels, ERK and PI3K signaling pathways in the effect of $\mathrm{H}_{2} \mathrm{~S}$ on proinflammatory cytokine production. (A, B, C, D, E and F) USMCs were treated with $\mathrm{NaHS}\left(10^{-4} \mathrm{M}\right)$ or L-cysteine $\left(10^{-3} \mathrm{M}\right)$ in combination with $\mathrm{K}_{\text {ATP }}$ channel inhibitor glibenclamide $\left(10^{-5} \mathrm{M}\right)$, ERK inhibitor PD98059 $\left(10^{-5} \mathrm{M}\right)$ and PI3K inhibitor LY294002 $\left(10^{-5} \mathrm{M}\right)$ for $24 \mathrm{~h}$. The supernatant was collected and levels of IL-1 $\beta$ (A and D), IL-6 (B and E) and TNF $\alpha$ (C and F) were measured by ELISA. (G, $\mathrm{H}$, I and J) USMCs were treated with $\mathrm{NaHS}\left(10^{-4} \mathrm{M}\right)$, L-cysteine $\left(10^{-3} \mathrm{M}\right)$ or vehicle for indicated time. Cells were collected and Western blot analysis was used to determine protein levels of ERK1/2 ( $\mathrm{G}$ and $\mathrm{H}$ ), p-ERK1/2 (G and H), PI3K (I and J) and p-PI3K (I and J). Representative protein bands are presented on the top of the responding histogram. Values are presented as mean \pm S.E.M. for $n=4$ subjects performed in triplicate. ${ }^{*} P<0.05,{ }^{* *} P<0.01$ vs vehicle control. Gliben, glibenclamide. 
A

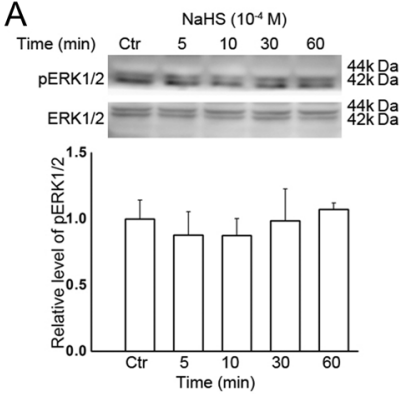

C
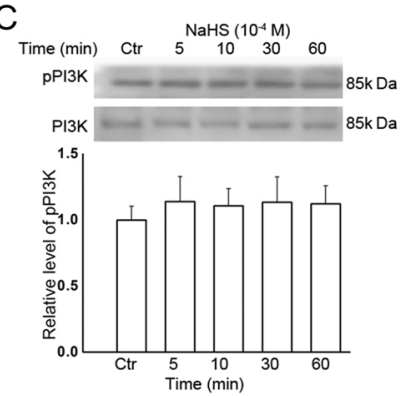

E

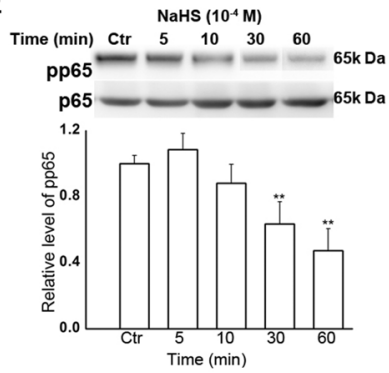

B

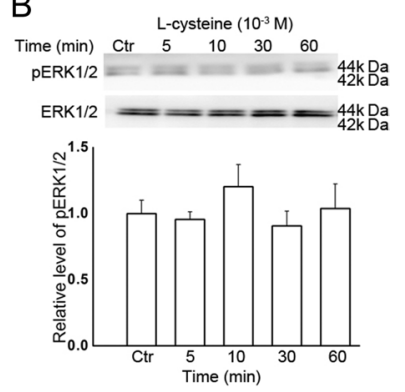

D
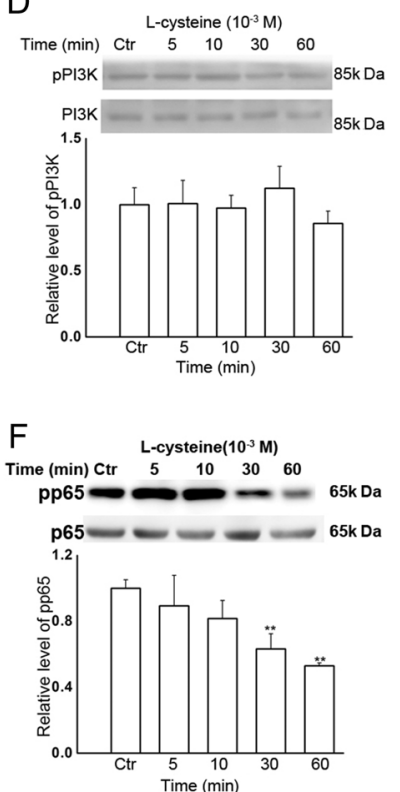

Figure 6 The role of $\mathrm{K}_{\text {ATP }}$ channels in $\mathrm{H}_{2} \mathrm{~S}$ activation of $\mathrm{PI} 3 \mathrm{~K}$ and ERK signaling and suppression of $\mathrm{NF}-\mathrm{KB}$ activation. USMCs were treated with $\mathrm{NaHS}\left(10^{-4} \mathrm{M}\right)$ or L-cysteine $\left(10^{-3} \mathrm{M}\right)$ in the presence of glibenclamide $\left(10^{-5} \mathrm{M}\right)$ for indicated time. Cells were collected and Western blot analysis was used to determine protein levels of ERK1/2 ( $\mathrm{A}$ and $\mathrm{B}), \mathrm{p}-\mathrm{ERK} 1 / 2$ (A and $\mathrm{B}), \mathrm{PI} 3 \mathrm{~K}(\mathrm{C}$ and $\mathrm{D}), \mathrm{p}-\mathrm{PI} 3 \mathrm{~K}(\mathrm{C}$ and $\mathrm{D})$, p-65 ( $E$ and F) and p-p65 (E and F). Representative protein bands are presented on the top of the responding histogram. Values are presented as mean \pm S.E.M. for $n=4$ subjects performed in triplicate. ${ }^{*} P<0.05,{ }^{* *} P<0.01$ vs vehicle control.

of inflammatory mediators (Tamizhselvi et al. 2009, Ang et al. 2011, Du et al. 2014, Li et al. 2016). However, some studies also demonstrated that $\mathrm{H}_{2} \mathrm{~S}$ could act as a proinflammatory mediator in the inflammatory responses (Bhatia et al. 2005, 2008, Ang et al. 2011). More recently, Badiei and coworkers (Badiei et al. 2016) reported that knockdown of CSE in these cells can protect the mice against pancreatitis, and therefore, proposed that endogenous $\mathrm{H}_{2} \mathrm{~S}$ produced by CSE is an endogenous inflammatory mediator in monocytes/ macrophages. The present study showed that exogenous $\mathrm{H}_{2} \mathrm{~S}$ and $\mathrm{H}_{2} \mathrm{~S}$ produced by CSE and CBS suppressed NF- $\mathrm{KB}$ activation and inhibited IL-1 $\beta$, IL- 6 and TNF $\alpha$ production in USMCs. Collectively, it may suggest that

the effect of $\mathrm{H}_{2} \mathrm{~S}$ on inflammatory response is dependent on the machinery of the target tissues.

Some studies have demonstrated that $\mathrm{H}_{2} \mathrm{~S}$ affects the expression of proinflammatory cytokines by modulating NF-кB activity (Guo et al. 2013, Du et al. 2014). In consistence with these studies, we also found that $\mathrm{H}_{2} \mathrm{~S}$ suppressed the level of phospho-p65, the active form of NF-KB, in myometrial biopsies. Of note, $\mathrm{K}_{\mathrm{ATP}}$ channels were firstly identified to mediate the dilatory effects of $\mathrm{H}_{2} \mathrm{~S}$ in vasculatures (Tang et al. 2010). Our previous studies have shown that $\mathrm{H}_{2} \mathrm{~S}$ suppresses the spontaneous contraction of human myometrial strips via $K_{\text {ATP }}$ channels (You et al. 2011). In the present study, we demonstrated that blockage of $\mathrm{K}_{\text {ATP }}$ channels reversed $\mathrm{H}_{2} \mathrm{~S}$ suppression of proinflammatory cytokines. In addition, we showed that the impact of $\mathrm{H}_{2} \mathrm{~S}$ on NF-KB activity was not dependent on $\mathrm{K}_{\text {ATP }}$ channels. A number of studies have implicated that $\mathrm{H}_{2} \mathrm{~S}$ actually exerts its function by modifying L-cysteine in a large number of proteins by S-sulfhydration (Mustafa et al. 2011, Du et al. 2014, Módis et al. 2016, Sun et al. 2016). Moreover, it has been reported that $\mathrm{H}_{2} \mathrm{~S}$ regulates NF- $\mathrm{\kappa B}$ activity and $\mathrm{K}_{\text {ATP }}$ channels via sulfhydration of L-cysteine in these proteins (Mustafa et al. 2011, Du et al. 2014). Taken together, it suggests that $\mathrm{H}_{2} \mathrm{~S}$ suppresses the production of proinflammatory cytokines by regulating the activity of NF-KB and $\mathrm{K}_{\text {ATP }}$ channels in pregnant USMCs.

The present study also showed that PI3K and ERK signaling pathways were involved in $\mathrm{H}_{2} \mathrm{~S}$ suppression of inflammation. Many studies have demonstrated that $\mathrm{PI} 3 \mathrm{~K}$ signaling is a negative regulator during inflammatory responses, such as lipopolysaccharide (LPS)-induced inflammatory response (Schabbauer et al. 2004, Luyendyk et al. 2007, Zhang et al. 2007, Bi et al. 2016). For instance, Zhang and coworkers (Zhang et al. 2007) reported that $\alpha$-lipoic acid attenuates LPSinduced inflammation via activation of PI3K signaling. Moreover, in pancreatic cells, it has been shown that $\mathrm{H}_{2} \mathrm{~S}$ suppresses caerulein-induced IL-1 $\beta$ and TNF $\alpha$ production via PI3K signaling ( $\mathrm{Bi}$ et al. 2016). Many studies have demonstrated that ERK signaling also promotes inflammatory responses in many tissues (Guha \& Mackman 2001, Maeng et al. 2006, Mandrekar \& Szabo 2009, Youn et al. 2016). However, some other studies reported that ERK signaling can serve as an anti-inflammation signaling in some tissues. Maeng and coworkers (Maeng et al. 2006) showed that activation of ERK suppresses NF-kB-dependent genes in endothelial cells. More recently, Subedi and coworkers (Subedi et al. 2016) demonstrated that the extract of Lindera neesiana, an herb medicine, decreased the production of proinflammatory cytokines and nitric oxide via ERK signaling pathway in neural cell lines. With regard to the mechanism by which $\mathrm{H}_{2} \mathrm{~S}$ induces $\mathrm{PI} 3 \mathrm{~K}$ and ERK signaling pathways, we found that $\mathrm{H}_{2} \mathrm{~S}$ activation of PI3K and ERK signaling is dependent on $\mathrm{K}_{\text {ATP }}$ channels, which is consistent with the study by $\mathrm{Hu}$ 
and coworkers (Hu et al. 2008) in which they showed that $\mathrm{H}_{2} \mathrm{~S}$ activates $\mathrm{PI} 3 \mathrm{~K}$ and ERK signaling via $\mathrm{K}_{\text {ATP }}$ channels in cardiomyocytes.

Human parturition is an inflammatory process, which includes increased the expression and secretion of inflammatory cytokines and chemokines in uterus. Our previous study has demonstrated that human parturition is associated with the activation of inflammatory processes in uterus as evidenced by the activation of NFKB leading to increased expression of CAPs in myometrium (You et al. 2014). In the present study, we showed that downregulation of $\mathrm{H}_{2} \mathrm{~S}$-producing enzymes CSE and CBS is associated with increased expression of CAPs and level of active NF- $\kappa \mathrm{B}$ in myometrium during pregnancy. In vitro study, we found that $\mathrm{H}_{2} \mathrm{~S}$ suppression of CAP expression, NF- $\mathrm{\kappa B}$ activation and the production of proinflammatory cytokines. Collectively, our data show that endogenous $\mathrm{H}_{2} \mathrm{~S}$ produced locally play a critical role in the maintenance of uterine quiescence, and this effect is associated with suppression of inflammation in uterus.

In conclusion, $\mathrm{H}_{2} \mathrm{~S}$ produced by CSE and CBS suppresses the expression of CAPs via inhibition of $\mathrm{NF}-\mathrm{\kappa B}$ and proinflammatory cytokines in pregnant human myometrial cells. The inhibitory effect of $\mathrm{H}_{2} \mathrm{~S}$ on proinflammatory cytokines is dependent on activation of $\mathrm{K}_{\text {ATP }}$ channels. Our data indicate that $\mathrm{H}_{2} \mathrm{~S}$ plays a critical role in the maintenance of uterine quiescence during pregnancy.

\section{Supplementary data}

This is linked to the online version of the paper at http://dx.doi. org/10.1530/REP-16-0549.

\section{Declaration of interest}

The authors declare that there is no conflict of interest that could be perceived as prejudicing the impartiality of the research reported.

\section{Funding}

National Natural Science Foundation of China (Nos. 81620108013, 81370734, 31371175 and 81471479) and the Global Alliance for the Prevention of Prematurity and Stillbirth (GAPPS) Preventing Preterm Birth Initiative, an initiative of Seattle Children's Hospital.

\section{Acknowledgement}

The authors wish to thank the nursing and medical staff of the delivery suite and the patients at Changhai Hospital and Maternity for their participation.

\section{References}

Ang SF, Moochhala SM, MacAry PA \& Bhatia M 2011 Hydrogen sulphide and neurogenic inflammation in polymicrobial sepsis: involvement of substance $\mathrm{P}$ and ERK-NF-KB signaling. PLOS ONE 6 e24535. (doi:10.1371/journal.pone.0024535)

Badiei A, Chambers ST, Gaddam RR \& Bhatia M 2016 Cystathionine- $\gamma$ lyase gene silencing with siRNA in monocytes/macrophages attenuates inflammation in cecal ligation and puncture-induced sepsis in the mouse. Journal of Biosciences 41 87-95. (doi:10.1007/s12038-0169598-9)

Bhatia M, Sidhapuriwala J, Moochhala SM \& Moore PK 2005 Hydrogen sulphide is a mediator of carrageenan-induced hindpaw oedema in the rat. British Journal of Pharmacology 145 141-144. (doi:10.1038/ sj.bjp.0706186)

Bhatia M, Sidhapuriwala JN, Ng SW, Tamizhselvi R \& Moochhala SM 2008 Pro-inflammatory effects of hydrogen sulphide on substance P in caerulein-induced acute pancreatitis. Journal of Cellular and Molecular Medicine 12 580-590. (doi:10.1111/j.1582-4934.2007.00131.x)

Bi CL, Wang H, Wang YJ, Sun J, Dong JS, Meng X \& Li JJ 2016 Selenium inhibits Staphylococcus aureus-induced inflammation by suppressing the activation of the NF- $\mathrm{BB}$ and MAPK signalling pathways in RAW264.7 macrophages. European Journal of Pharmacology $\mathbf{7 8 0}$ 159-165. (doi:10.1016/j.ejphar.2016.03.044)

Challis JRG, Matthews SG, Gibb W \& Lye SJ 2000 Endocrine and paracrine regulation of birth at term and preterm. Endocrine Reviews 21 514-550. (doi:10.1210/er.21.5.514)

Condon JC, Hardy DB, Kovaric K \& Mendelson CR 2006 Up-regulation of the progesterone receptor (PR)-C isoform in laboring myometrium by activation of nuclear factor-kappaB may contribute to the onset of labor through inhibition of PR function. Molecular Endocrinology 20 764-775. (doi:10.1210/me.2005-0242)

Du J, Huang Y, Yan H, Zhang Q, Zhao M, Zhu M, Liu J, Chen SX, Bu D, Tang C et al. 2014 Hydrogen sulphide suppresses oxidized low-density lipoprotein (ox-LDL)-stimulated monocyte chemoattractant protein 1 generation from macrophages via the nuclear factor $\kappa \mathrm{B}(\mathrm{NF}-\kappa \mathrm{B})$ pathway. Journal of Biological Chemistry 289 9741-9753. (doi:10.1074/jbc. M113.517995)

Gomez-Lopez N, Vadillo-Perez L, Hernandez-Carbajal A, GodinesEnriquez M, Olson DM \& Vadillo-Ortega F 2011 Specific inflammatory microenvironments in the zones of the fetal membranes at term delivery. American Journal of Obstetrics and Gynecology 205 e15-e24. (doi:10.1016/j.ajog.2011.04.019)

Guha M \& Mackman N 2001 LPS induction of gene expression in human monocytes. Cell Signaling 13 85-94. (doi:10.1016/S08986568(00)00149-2)

Guo R, Wu K, Chen J, Mo L, Hua X, Zheng D, Chen P, Chen G, Xu W \& Feng J 2013 Exogenous hydrogen sulphide protects against doxorubicininduced inflammation and cytotoxicity by inhibiting p38MAPK/NFkB pathway in H9c2 cardiac cells. Cellular Physiology and Biochemistry 32 1668-1680. (doi:10.1159/000356602)

Holwerda KM, Bos EM, Rajakumar A, Ris-Stalpers C, van Pampus MG, Timmer A, Erwich JJ, Faas MM, van Goor H \& Lely AT 2012 Hydrogen sulfide producing enzymes in pregnancy and preeclampsia. Placenta 33 518-521. (doi:10.1016/j.placenta.2012.02.014)

Hu Y, Chen X, Pan TT, Neo KL, Lee SW, Khin ES, Moore PK \& Bian JS 2008 Cardioprotection induced by hydrogen sulfide preconditioning involves activation of ERK and PI3K/Akt pathways. Pflügers Archiv 455 607-616. (doi:10.1007/s00424-007-0321-4)

Hu TX, Wang G, Guo XJ, Sun QQ, He P, Gu H, Huang Y, Gao L \& Ni X 2016 MiR 20a,-20b and -200c are involved in hydrogen sulfide stimulation of VEGF production in human placental trophoblasts. Placenta 39 101-110. (doi:10.1016/j.placenta.2016.01.019)

Jiang B, Tang G, Cao K, Wu L \& Wang R 2010 Molecular mechanism for $\mathrm{H}(2) \mathrm{S}$-induced activation of K(ATP) channels. Antioxidants and Redox Signaling 12 1167-1178. (doi:10.1089/ars.2009.2894)

Kamel RM 2010 The onset of human parturition. Archives of Gynecology and Obstetrics 281 975-982. (doi:10.1007/s00404-010-1365-9)

Li L, Rose P \& Moore PK 2011 Hydrogen sulfide and cell signaling. Annual Review of Pharmacology and Toxicology 51 169-187. (doi:10.1146/ annurev-pharmtox-010510-100505) 
Li F, Zhang P, Zhang M, Liang L, Sun X, Li M, Tang Y, Bao A, Gong J, Zhang J et al. 2016 Hydrogen sulfide prevents and partially reverses ozone-induced features of lung inflammation and emphysema in mice. American Journal of Respiratory Cell and Molecular Biology 55 72-81. (doi:10.1165/rcmb.2015-0014OC)

Liu L, Johnson HL, Cousens S, Perin J, Scott S, Lawn JE, Rudan I, Campbell H, Cibulskis R, Li M et al. 2012 Child health epidemiology reference group of WHO and UNICEF. Global, regional, and national causes of child mortality: an updated systematic analysis for 2010 with time trends since 2000. Lancet 379 2151-2161. (doi:10.1016/S01406736(12)60560-1)

Luyendyk JP, Schabbauer GA, Tencati M, Holscher T, Pawlinski R \& Mackman N 2007 Genetic analysis of the role of the PI3K-Akt pathway in lipopolysaccharide-induced cytokine and tissue factor gene expression in monocytes/macrophages. Journal of Immunology 180 4218-4226. (doi:10.4049/jimmunol.180.6.4218)

Maeng YS, Min JK, Kim JH, Yamagishi A, Mochizuki N, Kwon JY, Park YW, Kim YM \& Kwon YG 2006 ERK is an anti-inflammatory signal that suppresses expression of NF-kappaB-dependent inflammatory genes by inhibiting IKK activity in endothelial cells. Cell Signaling 18 994-1005. (doi:10.1016/j.cellsig.2005.08.007)

Mandrekar P \& Szabo G 2009 Signalling pathways in alcohol-induced liver inflammation. Journal of Hepatology 50 1258-1266. (doi:10.1016/j. jhep.2009.03.007)

Módis K, Ju Y, Ahmad A, Untereiner AA, Altaany Z, Wu L, Szabo C \& Wang R 2016 S-Sulfhydration of ATP synthase by hydrogen sulfide stimulates mitochondrial bioenergetics. Pharmacological Research 113 116-124. (doi:10.1016/j.phrs.2016.08.023)

Mustafa AK, Sikka G, Gazi SK, Steppan J, Jung SM, Bhunia AK, Barodka VM, Gazi FK, Barrow RK, Wang R et al. 2011 Hydrogen sulfide as endothelium-derived hyperpolarizing factor sulfhydrates potassium channels. Circulation Research 109 1259-1268. (doi:10.1161/ CIRCRESAHA.111.240242)

Osman I, Young A, Ledingham MA, Thomson AJ, Jordan F, Greer IA \& Norman JE 2003 Leukocyte density and pro-inflammatory cytokine expression in human fetal membranes, decidua, cervix and myometrium before and during labour at term. Molecular Human Reproduction 9 41-45. (doi:10.1093/molehr/gag001)

Papapetropoulos A, Pyriochou A, Altaany Z, Yang G, Marazioti A, Zhou Z, Jeschke MG, Branski LK, Herndon DN, Wang R et al. 2009 Hydrogen sulfide is an endogenous stimulator of angiogenesis. PNAS 106 21972-21977. (doi:10.1073/pnas.0908047106)

Peake BF, Nicholson CK, Lambert JP, Hood RL, Amin H, Amin S \& Calvert JW 2013 Hydrogen sulfide preconditions the $\mathrm{db} / \mathrm{db}$ diabetic mouse heart against ischemia-reperfusion injury by activating Nrf2 signaling in an Erk-dependent manner. American Journal of Physiology: Heart and Circulatory Physiology 304 H1215-H1224. (doi:10.1152/ ajpheart.00796.2012)

Rinaldi SF, Hutchinson JL, Rossi AG \& Norman JE 2011 Anti-inflammatory mediators as physiological and pharmacological regulators of parturition. Expert Review of Clinical Immunology 7 675-696. (doi:10.1586/ eci.11.58)

Romero R, Espinoza J, Gonçalves LF, Kusanovic JP, Friel LA \& Nien JK 2006 Inflammation in preterm and term labour and delivery. Seminars in Fetal and Neonatal Medicine 11 317-326. (doi:10.1016/j.siny.2006.05.001)

Schabbauer G, Tencati M, Pedersen B, Pawlinski R \& Mackman N 2004 PI3K-Akt pathway suppresses coagulation and inflammation in endotoxemic mice. Arteriosclerosis, Thrombosis, and Vascular Biology 24 1963-1969. (doi:10.1161/01.ATV.0000143096.15099.ce)

Shynlova O, Lee YH, Srikhajon K \& Lye SJ 2013 Physiologic uterine inflammation and labor onset: integration of endocrine and mechanical signals. Reproductive Sciences 20 154-167. (doi:10.1177/1933719112446084)

Skovgaard N, Gouliaev A, Aalling M \& Simonsen U 2011 The role of endogenous $\mathrm{H}_{2} \mathrm{~S}$ in cardiovascular physiology. Current Pharmaceutical Biotechnology 12 1385-1393. (doi:10.2174/138920111798280956)

Subedi L, Gaire BP, Do MH, Lee TH \& Kim SY 2016 Anti-neuroinflammatory and neuroprotective effects of the Lindera neesiana fruit in vitro. Phytomedicine 23 872-881. (doi:10.1016/j.phymed.2016.05.002)

Sun J, Aponte AM, Menazza S, Gucek M, Steenbergen C \& Murphy E 2016 Additive cardioprotection by pharmacological postconditioning with hydrogen sulfide and nitric oxide donors in mouse heart: S-sulfhydration vs S-nitrosylation. Cardiovascular Research 110 96-106. (doi:10.1093/ cvr/cvw037)

Tamizhselvi R, Sun J, Koh YH \& Bhatia M 2009 Effect of hydrogen sulfide on the phosphatidylinositol 3-kinase-protein kinase B pathway and on caerulein-induced cytokine production in isolated mouse pancreatic acinar cells. Journal of Pharmacology and Experimental Therapeutics 329 1166-1177. (doi:10.1124/jpet.109.150532)

Tang G, Wu L \& Wang R 2010 Interaction of hydrogen sulfide with ion channels. Clinical and Experimental Pharmacology and Physiology 37 753-763. (doi:10.1111/j.1440-1681.2010.05351.x)

Thomson AJ, Telfer JF, Young A, Campbell S, Stewart CJ, Cameron IT, Greer IA \& Norman JE 1999 Leukocytes infiltrate the myometrium during human parturition: further evidence that labour is an inflammatory process. Human Reproduction 14 229-236. (doi:10.1093/ humrep/15.1.229)

You XJ, Xu C, Lu JQ, Zhu XY, Gao L, Cui XR, Li Y, Gu H \& Ni X 2011 Expression of cystathionine $\beta$-synthase and cystathionine $\gamma$-lyase in human pregnant myometriumand their roles in the control of uterine contractility. PLOS ONE 6 e23788. (doi:10.1371/journal.pone.0023788)

You X, Gao L, Liu J, Xu C, Liu C, Li Y, Hui N, Gu H \& Ni X 2012 CRH activation of different signaling pathways results in differential calcium signaling in human pregnant myometrium before and during labor. Journal of Clinical Endocrinology and Metabolism 97 E1851-E1861. (doi:10.1210/jc.2011-3383)

You X, Liu J, Xu C, Liu W, Zhu X, Li Y, Sun Q, Gu H \& Ni X 2014 Corticotropinreleasing hormone $(\mathrm{CRH})$ promotes inflammation in human pregnant myometrium: the evidence of $\mathrm{CRH}$ initiating parturition? Journal of Clinical Endocrinology and Metabolism 99 E199-E208. (doi:10.1210/ jc.2013-3366)

Youn GS, Lee KW, Choi SY \& Park J 2016 Overexpression of HDAC6 induces pro-inflammatory responses by regulating ROS-MAPK-NF- $\kappa$ B/ AP-1 signaling pathways in macrophages. Free Radical Biology and Medicine 97 14-23. (doi:10.1016/j.freeradbiomed.2016.05.014)

Wallace JL, Ferraz JG \& Muscara MN 2012 Hydrogen sulfide: an endogenous mediator of resolution of inflammation and injury. Antioxidants and Redox Signaling 17 58-67. (doi:10.1089/ars.2011.4351)

Zhang WJ, Wei H, Hagen T \& Frei B 2007 Alpha-lipoic acid attenuates LPS induced inflammatory responses by activating the phosphoinositide 3-kinase/Akt signaling pathway. PNAS 104 4077-4082. (doi:10.1073/ pnas.0700305104)

Received 5 October 2016

First decision 14 November 2016

Revised manuscript received 22 January 2017

Accepted 10 February 2017 